ДВНЗ “Тернопільський державний медичний університет

імені І. Я. Горбачевського МОЗ Украӥни”

\title{
ПЕРЕВАГИ САМООСВІТНЬОЇ ДІЯЛЬНОСТІ МАЙБУТНІХ МАГІСТРІВ МЕДСЕСТРИНСТВА В УМОВАХ ДИСТАНЦІЙНОГО НАВЧАННЯ
}

\author{
I. M. Melnychuk, S. O. Yastremska \\ I. Horbachevsky Ternopil State Medical University

\begin{abstract}
THE ADVANTAGES OF SELF-EDUCATIONAL ACTIVITIES FOR THE
\end{abstract} \\ FUTURE MASTERS OF NURSING WITHIN THE DISTANCE LEARNING
}

\begin{abstract}
Мета роботи - виявлення переваг, що сприяють формуванню самоосвітньої компетенції у майбутніх магістрів медсестринства засобами дистанційного навчання.

Основна частина. Аналіз наукових інтерпретацій поняття “самоосвіта” дозволив нам визначити самоосвітню компетентність як інтегровану характеристику особистості, що поєднує знання, вміння, способи і досвід самоосвіти і виявляється в потребі, здатності й готовності до реалізації такого виду діяльності, спрямованої на досягнення особистісної, професійної, соціальної самореалізації особистості. У статті відображено основні теоретичні підходи до визначення поняття “самоосвітня компетентність майбутніх магістрів медсестринства”, представлено результати діагностики цього особистісно-професійного утворення. В результаті наукової розвідки ми виокремили чотири компоненти в структурі самоосвітньої компетентності студентів медичних закладів вищої освіти.

Наголошено на необхідності нових підходів до організації навчального процесу в магістратурі медсестринського спрямування, i, передусім, це стосується організації самоосвітньої діяльності майбутніх магістрів медсестринства засобами дистанційного навчання.

Висновок. Доведено, що потенціал електронного інформаційно-освітнього середовища створює необхідні умови для проектування студентами індивідуальної траєкторії самоосвіти, створення електронного кейса багажу знань, підвищує рівень емоційного сприйняття інформації, здійснює самоконтроль результатів навчальної діяльності, активізує самостійну пізнавальну ініціативність, мотивує студентів до самонавчання.
\end{abstract}

Ключові слова: майбутні магістри медсестринства; самоосвіта; самоосвітня компетентність; самоконтроль; електронне інформаційно-освітнє середовище; засоби дистанційного навчання.

The aim of the work - to identify the benefits that contribute to the formation of self-educational competence in future masters of nursing by means of distance learning.

The main body. The analysis of scientific interpretations of the concept of "self-education" allowed us to define self-educational competence as an integrated personality characteristic that combines knowledge, skills, methods and experience of self-education and manifests itself in the need, ability and readiness for implementation of such kind of activity aimed at achieving personal, professional, and social self-realization. The article reflects the main theoretical approaches to the definition of the concept of "self-educational competence of future masters of nursing"; the results of diagnostics of this person-professional phenomenon are presented. As a result of scientific research, we have identified four components in the structure of self-educational competence of students of Medical Institution of Higher Education.

The necessity of new approaches to the organization of the educational process in the magistracy of nursing is emphasized. First of all, this concerns the organization of self-education of future masters of nursing by means of distance learning.

Conclusion. It is proved that the potential of the digital informational and educational environment creates the necessary conditions for students to design an individual trajectory of self-education and create a digital portfolio of knowledge; it increases the level of emotional perception of information, caries out self-control of the results of educational activities, activates an independent cognitive initiative, and motivates students to self-study.

Key words: future masters of nursing; self-education; self-educational competence; self-control; digital informational and educational environment; means of distance learning.

Вступ. У сучасному інформаційному суспільстві динамічно зростають вимоги до професійних якостей фахівців. У цьому контексті безперервна

(c) І. М. Мельничук, С. О. Ястремська самоосвіта $є$ однією з головних умов успішного розвитку людського суспільства, світу в цілому i, звичайно, умовою життєвого успіху кожної окремо взятої особистості [1]. Особливого значення 
набуває самоосвіта в контексті навчання протягом життя, при якому основним суб’єктом планування, організації, регулювання і здійснення освіти може виступати тільки сама людина, а процес освіти переростає в процес самоосвіти.

Разом $з$ тим, більшість студентів медичних закладів вищої освіти (MЗВО) не готові і не вміють ефективно організувати процес самоосвітньої діяльності.

Отже, в сучасних умовах актуалізується проблема формування самоосвітньої компетентності студентів МЗВО, вирішення якої сприятиме підвищенню якості підготовки майбутніх фахівців у контексті глобалізації освіти і підвищення їх конкурентоспроможності на ринку праці [2].

У сучасній науково-педагогічній літературі нагромаджено достатньо інформації, що може бути основою для вирішення проблеми дослідження. Питання компетентнісного підходу в професійній освіті розглянуті в працях вітчизняних та зарубіжних науковців: В. Антипової, В. Бездухова, Н. Бібік, В. Болотова, Ю. Варданяна, В. Вербицького, Ф. Гоноболіна, І. Зимньої, І. Зязюна, І. Колеснікової, Н. Кузьміної, Г. Лежніної, О. Локшиної, М. Лук’янової, А. Маркової, О. Овчарук, Г. Пахомової, О. Пометун, М. Філатова, Р. Хайгерті, А. Хуторського та ін.

Історичні аспекти проблеми самоосвіти відображені в працях А. Айзенберга, А. Громцева, П. Камерева, Б. Райського та ін. Сутність, особливості та функції самоосвіти, її місце в професійній діяльності фахівця визначені в роботах Н. Кузьміної,
I. Наумченко, Г. Сухобскої та ін. Шляхи та засоби формування потреби в самоосвіті досліджені Г. Гнездиловим, Б. Райським, І. Редковець та ін.

Водночас такі інноваційні тенденції вітчизняної освіти, як: розвиток інформаційних технологій (С. Гончаренко, В. Красільнікова, Є. Полат та інші), зміна ролі самоосвіти на сучасному етапі розвитку суспільства, впровадження багаторівневої системи в практику МЗВО, призводять до виникнення й розширення протиріч між зростанням вимог суспільства до постійного підвищення рівня освіченості та конкурентоспроможності особистості й непідготовленістю більшості студентів вищої школи підвищувати цей рівень у процесі самоосвіти [3]. Існує протиріччя й між необхідністю формування самоосвітньої компетентності студентів МЗВО в процесі вивчення дисциплін професійного спрямування і нерозробленістю змісту і педагогічних умов формування цієї компетенції в освітньому процесі МЗВО.

Мета роботи - виявлення переваг, що сприяють формуванню самоосвітньої компетенції у майбутніх магістрів медсестринства засобами дистанційного навчання.

Основна частина. Нині необхідні нові підходи до організації навчального процесу в магістратурі медсестринського напряму, i, передусім, це стосується самостійної роботи та самоосвітньої діяльності магістрантів. Застосування такого ресурсу, як самоосвіта (самоосвітня діяльність), відкриває для майбутніх магістрів медсестринства додаткові переваги, відображені на рисунку 1.

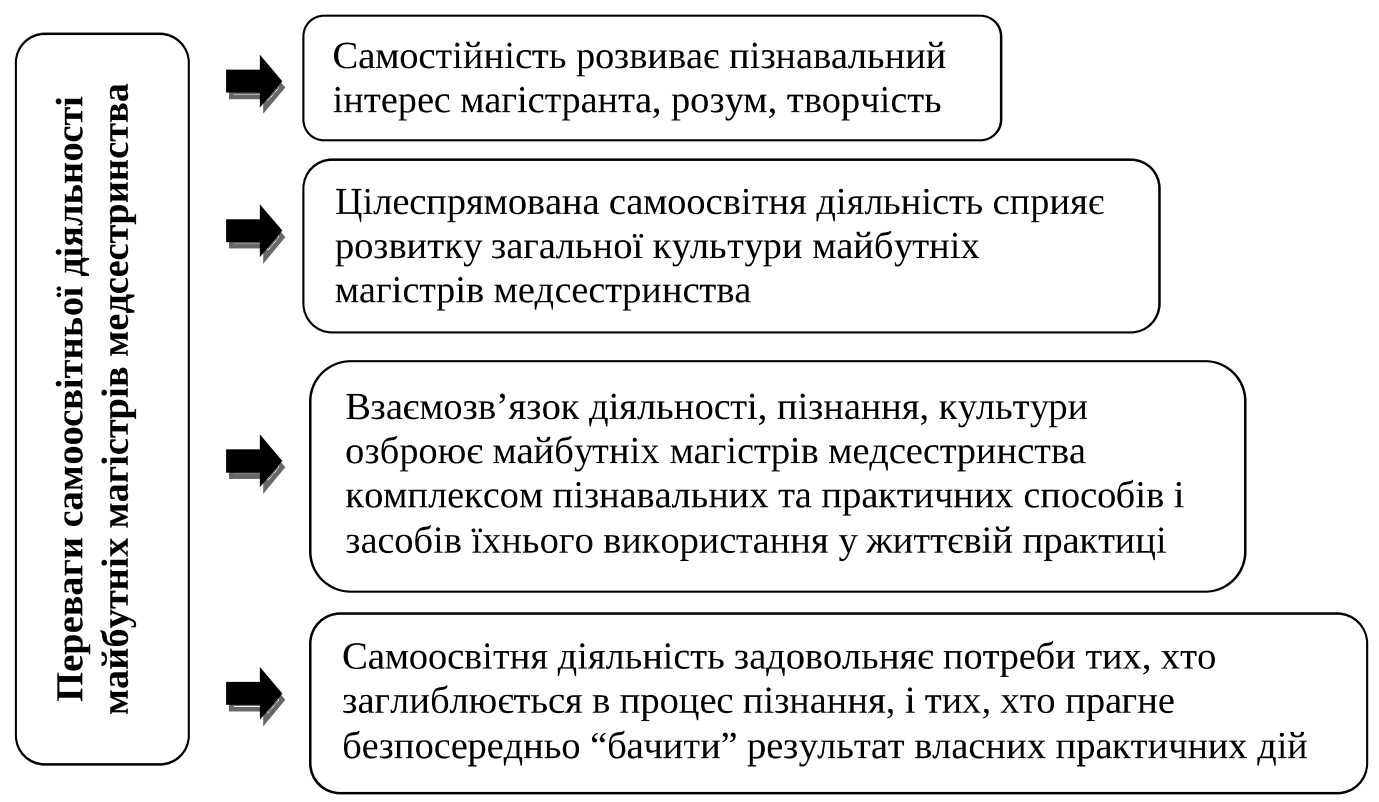

Рис. 1. Переваги самоосвітньої діяльності майбутніх магістрів медсестринства. 
Зокрема, в роботах американських дослідників C. Меріана та P. Кафелла (S. Merriam, R. Caffarella) самоосвітня діяльність трактується як форма навчання, в якій студенти несуть основну відповідальність за планування, виконання та оцінювання свого досвіду навчання [4]. Тому пропонуємо розглядати самоосвіту майбутніх магістрів медсестринства як специфічний вид діяльності, який здійснюється особистістю на добровільних засадах з метою задоволення пізнавальних потреб або покращення власних особистісних властивостей і здібностей.

У такому розумінні самоосвіти підкреслюється їі діяльнісний складник [5], який реалізується відповідно до задуму самої особистості (тобто цілі самоосвіти визначаються особистістю або сприймаються нею як власні) [6]. Отже, суть самоосвітньої діяльності полягає в тому, що особистість є суб’єктом своєї діяльності щодо досягнення внутрішньо засвоєних нею цілей, які становлять основний мотив самоосвіти.

3 огляду на зміни в цільових характеристиках професійної підготовки майбутніх магістрів медсестринства, вважаємо, що самоосвітня діяльність - це цілеспрямована, самостійна, пізнавальна, практикозорієнтована діяльність щодо розширення наявних знань і компетенцій та отримання нових в одній або декількох сферах медсестринської діяльності; це процес самовдосконалення особистості майбутніх магістрів медсестринства. Отже, довготривале та якісне отримання та структурування знань відбувається в результаті самоосвітньої діяльності студентів.

Самоосвітня діяльність є ключовою в системі підготовки майбутніх магістрів медсестринства у МЗВО засобами дистанційного навчання, оскільки цей процес організовується з метою суб’єктного розвитку студента й охоплює послідовний збір, переробку й інтерпретацію професійно значущої інформації та є супутнім освітній діяльності в межах дистанційного навчання. Індивідуально-особистісний процес перетворення інформації в знання (самоосвіта) стає провідним видом діяльності в сучасному інформаційному суспільстві.

Однією з форм самоосвітньої діяльності є самостійна робота. Її відмінність від самоосвіти полягає в тому, що самостійна робота в основному породжується і керується ззовні, тоді як самоосвітня діяльність - внутрішніми мотивами, які, на думку Н. Воропай, виходять за межі навчальних [6]. Інколи самостійна робота і самоосвітня діяльність настільки тісно переплітаються, що їх складно розмежувати [7].
Організація ефективного процесу освіти і самоосвіти значною мірою визначається методами самоосвітньої діяльності в інформаційному середовищі [8], дидактичними властивостями реалізації яких є: можливість зберігання, переробки і передачі інформації будь-якого виду й обсягу та доступу до різних джерел інформації, організація Internet-конференцій, можливість використання сучасного програмного забезпечення професійного призначення. Одним із таких методів самоосвітньої діяльності є сучасні інформаційні засоби - сервіси Всесвітньої мережі “Інтернет”, які поєднують безліч світових інформаційних ресурсів [6, 9].

Для організації самоосвітньої роботи майбутніх магістрів медсестринства у МЗВО засобами дистанційного навчання також використовуються електронні навчальні курси, підручники, навчальні посібники, тренажери, лабораторні віртуальні практикуми, стенди, мережеві проекти, телеконференції, тематичні каталоги з окремих медсестринських сфер та ін. Тому нині ми розглядаємо можливості використання дистанційної самоосвіти, в межах якої студент та інформаційні джерела розділені в процесі навчання простором і часом. Освітній процес здійснюється з використанням комп'ютерних технологій та відеоконференцій, різних засобів отримання навчального матеріалу за допомогою web-сторінки, електронної пошти; дискусій учасників у web-форумах [10]. Отже, у системі професійної підготовки майбутніх магістрів медсестринства у МЗВО засобами дистанційного навчання використання всесвітньої інформаційної мережі сприяє встановленню атмосфери постійної самоосвіти студентів, їхнього перетворення в дієвих суб’єктів пізнання і спілкування.

Водночас проблема підвищення ефективності вищої медсестринської освіти полягає в пошуку шляхів вирішення протиріч між зростаючим обсягом навчальної інформації та тенденцією до скорочення нормативних термінів освоєння цієї інформації. У такому випадку досить дієвими є Інтернет і дистанційна самоосвіта. Тому для вирішення цієї проблеми у межах дослідження ми пропонуємо:

- планувати освітній процес на основі раціонального використання можливостей Інтернету, що уможливлює навчання майбутніх магістрів медсестринства в оптимальному для кожного темпі та за індивідуальною освітньою траєкторією;

- використовувати інформаційні технології (розробка програм дистанційного навчання) для контролю якості виконаної самоосвітньої роботи. 
Характеризуючи самоосвітню діяльність майбутніх магістрів медсестринства як вид діяльності, що спрямований на реалізацію потреб особистості в соціалізації, підвищенні освітнього рівня, отримання задоволення від здобутого самостійним шляхом знання, ми відзначаємо доступні, інформаційні, практико зорієнтовані можливості Інтернету в самоосвітній діяльності студента.

Аналіз різних інтерпретацій понять “самоосвіта" i “компетентність” дозволив нам визначити самоосвітню компетентність як інтегровану характеристику особистості, що включає в себе знання, вміння, способи й досвід самоосвіти, яка виявляється в потребі, здатності і готовності до реалізації даного виду діяльності, спрямованої на досягнення особистісної, професійної, соціальної самореалізації особистості [11]. В результаті аналізу психолого-педагогічної літератури нами виділено чотири компоненти в структурі самоосвітньої компетентності студентівмагістрантів спеціальності “Медсестринство”.

Перший компонент - мотиваційно-ціннісний, свідчить про сформованість потреби студентів до постійного саморозвитку та самовдосконалення, стійкого інтересу, що забезпечує позитивне ставлення до самоосвітньої діяльності, прагнення до постійної самоосвіти, усвідомлення її особистої і соціальної значущості.

Когнітивно-комунікативний компонент характеризує рівень знань студентів про сутність, форми, прийоми, способи самоосвіти, рівень володіння загальноосвітніми, предметними і професійними знаннями, здатність до безперервної особистої самоосвіти шляхом застосування сучасних інформаційно-телекомунікаційних технологій.

Операційно-діяльнісний компонент передбачає володіння сукупністю конструктивно-проектувальних, організаторських, комунікативних умінь, умінь самостійно організовувати свою самоосвітню діяльність, самостійно працювати з інформацією, проводити дослідження, виконувати міждисциплінарні проекти тощо.

Четвертий компонент - особистісно-рефлексивний - передбачає аналіз і самооцінку студентами своєї готовності до самоосвіти, адекватну оцінку своїх досягнень, потребу в рефлексії самоосвіти.

На констатувальному етапі експерименту, який проводився на базі Навчально-наукового інституту (ННI) медсестринства ТДМУ та КВНЗ “Житомирський медичний інститут” (ЖМІ), нами виділені три рівні сформованості самоосвітньої компетентності студентів: низький, середній та високий. Ре- зультати констатувального етапу експериментальної роботи показали, що в більшості студентів як контрольних, так і експериментальних груп самоосвітня компетентність сформована недостатньо: на низькому рівні - 47 \% (НHI) і 52 \% (ЖМI), на середньому рівні - 45 \% (НHI) і $42 \%$ (ЖМI), на високому рівні - 8 \% (НHI), 6 \% (ЖМI).

Формування компонентів самоосвітньої компетентності у студентів експериментальної групи здійснювалося шляхом застосування засобів дистанційного навчання (електронні підручники, електронні бібліотеки, комп'ютерні навчальні і тестуючі системи, слайд-лекції (відео-, аудіолекції), тематичні сайти в локальній мережі (Інтранет), електронні навчально-методичні комплекси) і створення електронного інформаційного освітнього середовища.

Використовувалася схема трифазного дистанційного навчання. На першій очній фазі відбувалось ознайомлення студентів із сайтом; присвоєння кожному студенту власного логіна і пароля, за допомогою яких уможливлюється вхід у систему; інструктаж стосовно організації навчання та контролю; апробація студентами входу в систему та організації комунікативної взаємодії з викладачами.

Друга - дистанційна фаза - передбачала самостійну роботу студентів з електронними освітніми ресурсами, розміщеними на порталі НHI медсестриства ТДМУ за електронною адресою: http://dl.tdmu.edu.ua. Під час дистанційної фази навчання використовувалися мережеві технології (автономні мережеві курси з використанням мережі “Інтернет”) та кейс-технології, засновані на комплектуванні наборів (кейсів) мультимедійних навчально-методичних матеріалів на електронних та інших носіях. За способом організації занять використовувалися дві форми дистанційного навчання - синхронне і асинхронне.

Третя, очна фаза, передбачала державний іспит публічний захист виконаної магістерської роботи. До захисту магістерської роботи студент допускався, якщо рейтинг за результатами підсумкового контролю становив не менше $50 \%$.

Динаміку змін у рівнях сформованості самоосвітньої компетентності можна охарактеризувати як рух від керованої викладачем самоосвітньої діяльності студента до самостійної самоосвітньої діяльності майбутнього фахівця, які викликані внутрішніми мотивами і потребами.

На заключному етапі ми провели повторні заміри рівнів сформованості самоосвітньої компетентнос- 
ті студентів МЗВО в контрольних і експериментальних групах, підсумки яких показали позитивні результати. Динаміка рівнів сформованості самоосвітньої компетентності наведена на рисунку 2.

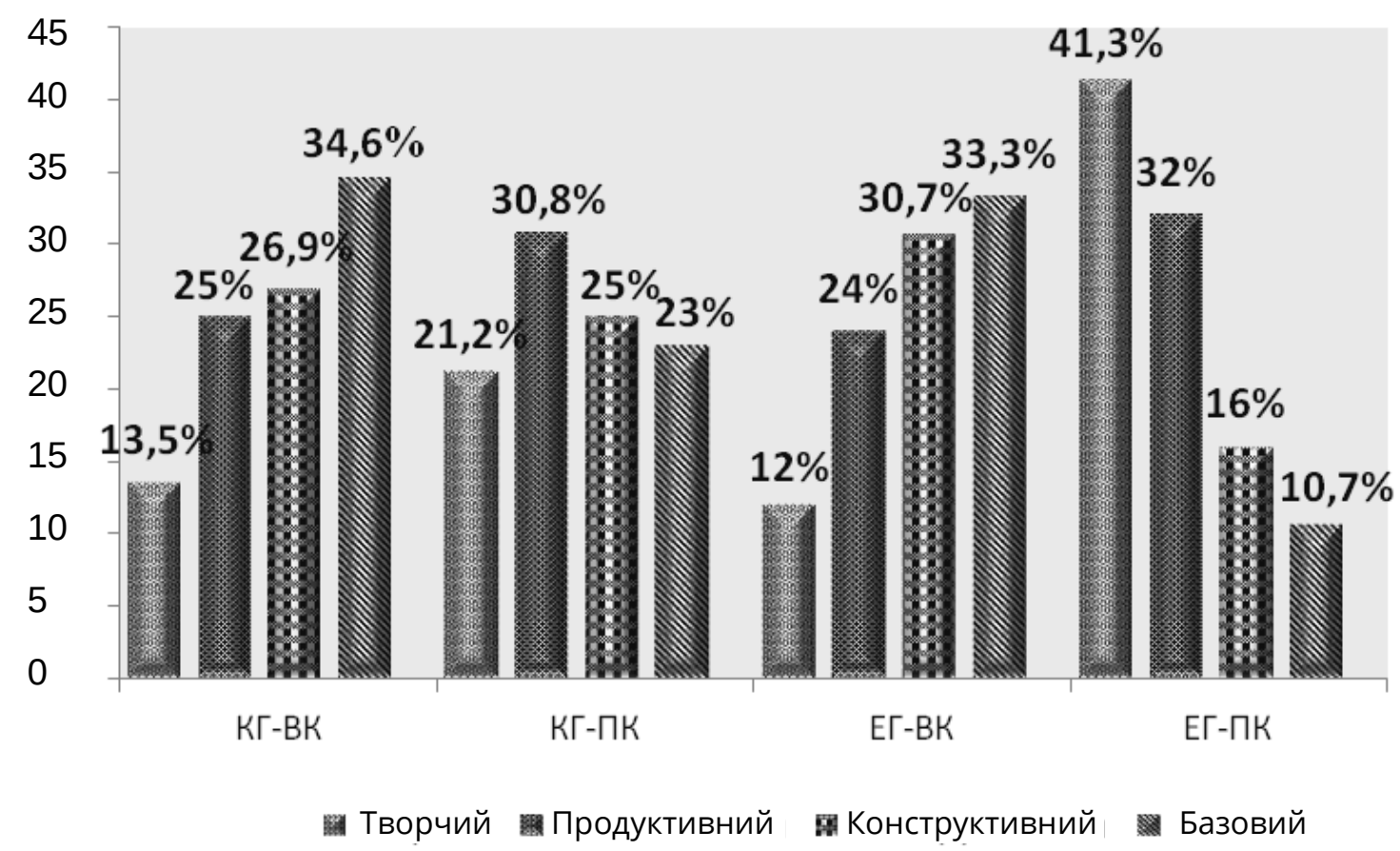

Рис. 2. Динаміка рівнів сформованості самоосвітньої компетентності майбутніх магістрів медсестринства.

Аналіз результатів показує однозначне підвищення рівня сформованості самоосвітньої компетентності в експериментальних групах, у той час як у контрольних групах зміни в позитивну сторону також відбулися, але незначні. Так, збільшилася кількість магістрантів з творчим рівнем на 7,7 \% у КГ і на 29,3 \% в ЕГ; збільшилася кількість студентів із продуктивним рівнем на 5,8 \% у КГ і на 8,0 \% в ЕГ; зменшилася кількість магістрантів з конструктивним та базовим рівнем, відповідно, на 1,9 \% та 14,7 \% у КГ та на 11,6 \% і 22,6 \% в ЕГ.

\section{Список літератури}

1. Овчарук О. Компетентності як ключ до оновлення змісту освіти / О. Овчарук // Стратегія реформування освіти в Україні: рекомендації з освітньої політики. K. : K.I.C, 2003. - 225 c.

2. Коростіль Л. А. Самоосвіта особистості як соціальне та педагогічне явище / Л. А. Коростіль // Педагогічні науки : зб. наук. праць. - Суми : Видавництво СумДПУ, 2009. - № 1. - С. 138-145.

3. Ястремська С. О. Інноваційний освітній процес підготовки майбутніх магістрів сестринської справи / С. О. Ястремська // Оновлення змісту, форм та методів навчання і виховання в закладах освіти : зб. наук. праць [Наукові записки Рівненського державного гуманітарного університету]. - Рівне, 2017. - Вип. 16 (59). C. 190-193.
Висновок. Таким чином, потенціал електронного інформаційно-освітнього середовища створює необхідні умови для проектування індивідуальної траєкторії самоосвіти, створення електронного кейса накопичених знань, підвищує рівень емоційного сприйняття інформації, здійснює самоконтроль студентів за результатами навчальної діяльності, активізує самостійну пізнавальну ініціативність, стимулює мотивацію до самонавчання.

4. Merriam S. B. Learning in Adulthood. A comprehensive guide / S. B. Merriam, R. S. Caffarella. - San Francisco : Jossey-Bass, 2011. - 229 p.

5. Hayes C. Beyond the American Dream. Lifelong learning and the search for meaning in a postmodern world / C. Hayes. - Wasilla : Autodidactic Press, 2008. - 365 p.

6. Воронова Л. И. Реформа медсестринского образования. Медсестринский процесс. Основные этапы / Л. И. Воронова, Л. П. Попова // Головна медична сестра. 2005. - № 5. - С. 46-49.

7. Пелещишин А. М. Методи та алгоритми моделювання Web-систем / A. М. Пелещишин. - URL : http://disser. com.ua/contents/31604.html (дата звернення 12.10.2015).

8. Топол І. Впровадження дистанційної форми навчання у навчальний процес медичних вишів / I. Топол // 
Сучасний стан та перспективи розвитку освітнього простору: глобальний вимір : матеріали Міжнар. наук.практ. Інтернет-конф. (Запоріжжя, 25 листоп. 2016 р.). Запоріжжя : ЗДІА, 2016. - С. 308-311.

9. Кисельова О. Б. Формування компетентності самоосвіти у майбутніх педагогів в умовах інформаційно-навчального середовища : автореф. дис. на здобуття наук. ступеня канд. пед. наук / О. Б. Кисельова. - Х., 2011. - 20 c.

\section{References}

1. Ovcharuk, O. (2003). Kompetentnosti yak kliuch do onovlennia zmistu osvity [Competencies as a key to updating the content of education]. Stratehiia reformuvannia osvity v Ukraini: rekomendatsii z osvitnoi polityky - Strategy for reforming education in Ukraine: recommendations for educational policy. Kyiv: "K.I.S” [in Ukrainian].

2. Korostil, L.A. (2009). Samoosvita osobystosti yak sotsialne ta pedahohichne yavyshche [Self-education of the individual as a social and pedagogical phenomenon]. Pedahohichni nauky: zb. nauk. prats. - Pedagogical sciences: Collection of Scientific works. Sumy: SumSPU Publishing House [in Ukrainian].

3. Yastremska, S.O. (2017). Innovatsiinyi osvitnii protses pidhotovky maibutnikh mahistriv sestrynskoi spravy [Innovative educational process of preparing future masters of nursing]. Onovlennia zmistu, form ta metodiv navchannia i vykhovannia v zakladakh osvity: zb. nauk. prats [Naukovi zapysky Rivnenskoho derzhavnoho humanitarnoho universytetu]. Rivne - Improvement of content, forms and methods of education and education in educational institutions: Collection of Scient. Works [Scientific Notes of Rivne State Humanitarian University], 16 (59), 190-193 [in Ukrainian].

4. Merriam, S.B., \& Caffarella, R. S. (2011). Learning in adulthood. A comprehensive guide. San Francisco: JosseyBass.

5. Hayes, C. (2008). Beyond the American dream. Lifelong learning and the search for meaning in a postmodern world. Wasilla: Autodidactic Press.

6. Voronova, L.I., \& Popova, L.P. (2005). Reforma medsestrynskogo obrazovaniya. Medsestrynskiy protsess. Osnovnye etapy [Nursing education reform. Nursing process. Basic steps]. Holovna medychna sestra-Chief Nurse, 5, 46-49 [in Russian].
10. Запорожан В. М. Взаємозв'язок мотивації досягнень та успіхів у навчанні у студентів медичного факультету / В. М. Запорожан, Л. Р. Нікогосян, К. В. Аймедов // Медична освіта. - 2011. - № 2. - С. 108-113.

11. Modeling and measuring competencies in higher education professional and vet learning / In: Sigrid Blömeke, Olga Zlatkin-Troitschanskaia, Christiane Kuhn, Judith Fege - eds. - 2014. - Vol. 1. - 231 p.

7. Peleshchyshyn, A.M. (2015). Metody ta alhorytmy modeliuvannia Web-system [Methods and algorithms for modeling Web-systems]. Retrieved from: http://disser.com. ua/contents/31604.html (application date dated 12.10.2015). [in Ukrainian].

8. Topol, I. (2016). Vprovadzhennia dystantsiinoi formy navchannia u navchalnyi protses medychnykh vyshiv [Implementation of distance learning in the educational process of medical universities]. Suchasnyi stan ta perspektyvy rozvytku osvitnoho prostoru: hlobalnyi vymir: materialy Mizhnar. nauk.-prakt. Internet-konf. - Current State and Prospects of Educational Space Development: Global Dimension: Materials of International Scientific Practical Internet Conference. November, 25. Zaporizhzhia: ZDIA [in Ukrainian].

9. Kyselova, O.B. (2011). Formuvannia kompetentnosti samoosvity u maibutnikh pedahohiv v umovakh informatsiino-navchalnoho seredovyshcha [Formation of competency of self-education of future teachers in conditions of informational and educational environment]. Candidate's Extended abstract [in Ukrainian].

10. Zaporozhan, V.M., Nikohosian, L.R., \& Aimedov, K.V. (2011). Vzaiemozviazok motyvatsii dosiahnen ta uspikhiv u navchanni u studentiv medychnoho fakultetu [The relationship between the motivation of achievements and the success of studying in students of the medical faculty]. Medychna osvita - Medical Education, 2, 108-113 [in Ukrainian].

11. Sigrid Blömeke, Olga Zlatkin-Troitschanskaia, Christiane Kuhn, \& Judith Fege (Eds.). (2014). Modeling and measuring competencies in higher education professional and vet learning. 